\title{
Kadın Girişimciliği ve Finansal Okuryazarlığın Ka- dın Girişimciler Üzerindeki Etkisi
}

\author{
DOI: $10.26466 /$ opus. 359920 \\ * \\ Doğan Kutukız - \\ * Doç. Dr., Muğla S1tkı Koçman Üniversitesi Turizm Fakültesi, Menteşe/Muğla/Türkiye \\ E-Posta: dkutukiz@yahoo.com \\ ORCID: 0000-0002-8363-2681 \\ ${ }^{* *}$ Y.L Öğr. Muğla Sıtkı Koçman Üniversitesi Turizm İşletmeciliği Anabilim dalı, \\ Menteşe/Muğla/Türkiye \\ E-Posta: cherenche@hotmail.com \\ ORCID: 0000-0003-3605-6105
}

Öz

Bireyin bütçe yönetiminde etkin finansal kararlar alma olarak tanımlanan finansal okuryazarlik; bireyin, hane halkının ve makro düzeyde toplumun refahının artmasına katkı să̆lamaktadır. Özellikle son yıllarda hem hane hem de ülke ekonomisine olan katkısı ile gün geçtikçe sayısı artan kadın girişimcilerin finansal okuryazarlık seviyesinin yükselmesi bu bağlamda oldukça önemlidir. Bireyin gelişim ve eğitim sürecinde payı olan bir kadının; finansal okuryazarlık düzeyinin hem çalışma hayatında hem de aile ortamında finansal bilgisi, davranışı ve tutumu açısından büyük bir etkisi olduğu düşünülmektedir. Bu çalışmada, Muğla ili Milas ilçesindeki kadın girişimcilerin finansal okuryazarlık seviyesinin ve finansal okuryazarlık konusundaki yeterliliklerinin tespit edilmesi amaçlanmıştır. Literatüre bakıldığında son yıllarda finansal okuryazarlık alanında yapılan çalışmalar giderek artmıştır. Fakat uygulamaların çoğunluğunun üniversite öğrencilerinin oluşturduğu araştırmalarda, kadın girişimciler üzerine çok fazla çalışma olmadığı görülmektedir. Bu açıdan çalışmanın ilgili literatüre farklı bir bakış açısı ile katkı sağlayacağı öngörülmektedir.

Anahtar Kelimeler: Finansal okuryazarlık, finansal davranış, finansal tutum, girişimcilik, kadın girişimciliŏ $i$, 


\title{
Woman Entrepreneurship and The Impact of Finan- cial Literacy on Women Entrepreneurs
}

\begin{abstract}
Financial literacy, defined as taking decisionmaking knowledge-based about budget keeping, contributes to increasing the welfare of individual, households, and the society at macrolevel. Especially, in recent years, with it's contribution to both home and national economy, it's important to rise of financial literacy level of the women entrepreneurs with contribution to both family budget and also national economy. Level of the financial literacy of woman, contributes to individual's growing and education process, is considered to be major influence both in the working life and in the family environment in terms of financial knowledge, behavior and attitude. In this study, it is aimed to be determined financial literacy level and sufficiency of the women entrepreneurs in Milas,Muğla. Considering literature, in last years, studies about financial literacy have increased gradually. However, in the studies mostly consistedof under graduates, it seems that there is no much surveys an upon women entrepreneurs. It is predicted that this study will contribute to the literature with different perspective.
\end{abstract}

Keywords: Financial literacy, Entrepreneurship, Woman entrepreneurship

OPUS (c) Uluslararası Toplum Araştırmaları Dergisi-International Journal of Society Researches ISSN:2528-9527 E-ISSN : 2528-9535

http://opusjournal.net 


\section{Giriş}

Ülke ekonomisinde ve kalkınma sürecinde önemli rol oynayan girişimciler; sosyo-kültürel, politik ve ekonomik alanlarda etkin bir şekilde sadece üretim faktörlerini kullanarak kar amacı güden kişiler değillerdir. Küreselleşme, işletmelerin ve girişimcilerin daha şiddetli bir rekabet ortamında çalışmalarını gerektirmektedir. Çünkü günümüzde uluslararası rekabete karşı devlet bünyesinde olan işletmecilik anlayışı yerine müşteri odaklı, sürekli kendini yenileyen, esnek ve hızlı üretim ve yönetim anlayışı hakim olmaya başlamıştır (Soysal,2010:84). Girişimciler, yeni bir düşünceyi faaliyete geçirdiği takdirde ülkenin hem ekonomisine hem de toplumuna yarar sağladığından dolayı ülkenin ekonomik gelişmesini de hızlandıracaktir.

Geçmişteki girişimcilik tanımlarına bakıldığında sadece erkeklere özgü bir alan olarak değerlendirildiği ama günümüzde bu tanımlara kadınların da dahil edildiği görülmektedir. Kadın ve erkek girişimciler benzer özelliklere sahip olmasının yanı sıra ortak sorunlarla da karşılaşmaktadırlar. Ama kadının toplumdaki yeri değerlendirildiğinde kadın girişimcilerin gerek aile gerekse de iş hayatı bakımından daha fazla sorumluluk aldıkları ve farklı sorunlarla da karşılaştıkları görülmektedir.

Esasında kadın girişimciler tarih boyunca farklı coğrafyalarda, kültürlerin birbirinden farklı özelliklere sahip olması nedeniyle çeşitli alanlarda olmak üzere iş hayatında hep var olmuştur (Terzi ve Kurt, 2015:126). Fakat 1980 yılından itibaren kadınlar; daha fazla meslek gruplarında aktif bir şekilde faaliyet göstermektedirler. Türkiye' de girişimcilik alanında kadınların karşılaştıkları finansal destek ve eğitim yetersizliği, ailevi sorumluluk bilinci ve toplumun kadınlara bakış açısından kaynaklanan sorunlara rağmen, kadınlar bireysel girişimde bulunabilmekte, bu da işletme sahibi olan kadınların sayısının her geçen gün artışını sağlamaktadır. Böylelikle kadınların girişimcilik faaliyetlerine katılımı sayesinde istihdam sağlanarak kalkınmanın gerçekleşmesinde büyük rol oynamaktadırlar (Erdun,2011:1).

2000'li yılların başlarında ekonomilerde yaşanan krizler, istikrarsızlıklar ve finansal araç çeşitliliğinin artışı, küreselleşmenin de etkisiyle tüketicilerin finansal davranış ve tutumlarında değişikliğe sebep olmuştur. Araştırmalara göre tüketicinin hem gündelik hemde iş 
hayatında finansal yönetim becerisi kazanmasının ve finansal okuryazar olmasının gerekliliğine değinilmiştir (Taft, Hosein, Mehrizi \& Roshan, 2013: 63). Son yıllarda finansal sistemde yaşanan bu değişiklikler nedeniyle, hem tüketici hem de üretici toplumun finansal alanda yaşanan her türlü değişim adına bu alanla daha iç içe olmaları ve bu alanda temel bilgi gereksinimi ihtiyacını doğurmuştur. Bu açıdan finansal okuryazarlık, finansal kararlarda bireye yardımcı olacak önemli bir kavram haline gelmiştir (Gökmen, 2012: 39).

Son yıllarda finansal okuryazarlık konusu devletler, politikacılar, bankalar, ekonomistler ve eğitimciler tarafından sıkça gündeme getirilmektedir ve finansal okuryazarlık literatüründe birbirinden farklı gruplara yönelik yapılan çalışmalara rastlanılmaktadır. İşletmelerin yanı sıra, bireyin her alanda kişisel finansal durumunu kontrol edebilmesi açısından hane halkına, özellikle mesleki alanda finansal bilgi gerektirdiği için yatırımc1lara ve finansal okuryazar olabilme temelinin oluşturulabileceği yaş grubunda olan çoğunun üniversite öğrencisi olduğu gruplara yönelik çalışmalar bulunmaktadır (Kılıç vd., 2015:4).

Finansal okuryazarlık seviyesini belirleme amacıyla yapılan çalışmalarda bireylerin finansal ortamdaki genel bilgi, tutum ve davranışlarının ölçülmesinin yanı sıra bazı demografik özelliklere göre (cinsiyet, eğitim durumu, yaş vb.) okuryazarlık seviyesinin farklılık yaratıp yaratmadığını da göz önünde bulunduran çalışmalar yapılmaktadır. Tüm dünyada yaygın olarak erkeklerin kadınlara, eğitim seviyesi yüksek olanların düşük olanlara ve orta yaş bireylerin genç ve yaşlı bireylere oranla finansal okuryazarlık düzeylerinin daha yüksek olduğu belirtilmiştir (Lusardi ve Mitchell, 2011: 500-508).

Günümüz dünyasında kadınları iş hayatında ve birçok farklı meslek gruplarında geçmiş yıllara oranla daha fazla görebilmekteyiz. Bu açıdan bakıldığında kadınların finansal okuryazarlık seviyesinin hem mesleki hayatında hem de aile hayatında rolünün büyük olduğu görülmektedir. Kadın girişimcilerin finansal okuryazarlık seviyesi, finansal okuryazarlık konusunda ki yeterlilikleri, bazı finansal kavramlar hakkında ki bilgi düzeyleri ve güncel finansal gelişmelerle ilgilenme durumlarının tespit edilmesi amacıyla yapılan bu çalışmada; finansal becerilerini okulda alınan eğitim sayesinde geliştirdiği ve ekonomik ve finansal gelişmeleri internet 
aracılığıyla takip ettiği ortaya çıkmıştır. Araştırmanın sonucu doğrultusunda bir bireyin finansal okuryazarlık düzeyinin aldığı eğitim ve günümüz dünyasında yeni bilgi edinmede en çok kullanılan internetin etkili olduğu görülmektedir.

\section{Girişimcilik ve kadın girişimciliği}

Girişimci, üretim faktörlerinden biridir. Diğer üretim faktörlerinin (emek, doğal kaynak ve sermaye) bir arada veya ayrı ayrı bulunması, üretim yapılması ya da ekonomik bir faaliyetin gerçekleştirilmesi için yeterli değildir. Bu faktörlerin bir araya getirilerek üretim sürecine dahil edilmesi ve ayrıca ekonomik bir değer üretmeye yardımcı olacağı düşünüldüğü için girişimciye gereksinim duyulmaktadır. Dolayısıyla üretim sürecinin başlaması ve devam etmesinde girişimcinin önemi büyüktür (Memiş vd., 2007:138).

İlk olarak Cantillon'un 1759 'da girişimciyi risk ve belirsizlik durumlarını yöneten kişi olarak tanımlamasının ardından Joseph Schumpeter girişimciyi "yeniliği sunan birey" olarak tanımlamıştır. Girişimciliğin tanımı konusunda farklı yaklaşımlar bulunmakla birlikte, bütün tanımlarında yenilikçi olması gerektiği düşüncesi hep yer almaktadır. Risk ve belirsizlik koşulları altında kazanç elde etme ve büyüme amacı ile yenilikçi bir ekonomik organizasyonu oluşturmak olarak tanımlanabilen girişimcilik, ayrıca fırsatları görerek onların atmosferinde iş kurabilen, bu iş fikrini en iyi şekilde pazarlayabilen, risk alarak kâr elde edebilen, teknolojik yenilikleri takip edecek yenilikçi bir kişilik, karar alma, maceracı ve liderlik gibi yeteneklere sahip cesareti yüksek kişi olarak da tanımlanmaktadır (Cici,2013:17).

Kadın girişimciliği genel olarak istihdam ve kadın istihdamının özel bir alanıdır. Kalkınma stratejilerinin önem kazanması ile Türkiye'de ancak 1980'li yıllardan sonra kadınların işgücüne katılımı gerçekleştirilebilmiştir. Kadın girişimciliği tanımına ait bir çok atıfın bulunmasından dolayı işletme bazında hangi özelliklere sahip kadınların girişimci olarak adlandırılıp hangilerinin adlandırılamayacağının belirlenmesi için kadın girişimci tanımı şu ortak özelliklere sahip olmalıdır (Bedük,2005:111);

- Ev dişındaki bir ortamda kendi adına kurduğu bir iş yeri olan, 
- $\mathrm{Bu}$ iş yerinde kendisi veya kendisi ile birlikte çalışan personel veya ortaklık olan,

- Mal veya hizmet üretmek amaciyla bir faaliyette bulunan ve ürettiği malın dağıtım, pazarlama ve satışını yapan/yaptıran,

- İşi ile ilgili olarak işletme adına kurum veya kuruluşlarla iletişimde bulunan,

- İşlerin örgütlenmesi, üretiminin planlanması, işletilmesi, kapatılması veya geliştirilmesi kararını veren,

- Elde ettiği kazancın yatırım ve kullanımı konusunda söz sahibi olan kadındır (Ecevit, 1993: 19-20).

Dünya nüfusunun yarısını ve işgücünün yaklaşık üçte birini oluşturan kadınların ekonomik hayatta katılmaları, değer üretme ve dolayısıyla da kalkınmayı sağlamada önemli etkileri olmasına karşın, ekonomik kalkınmadan yararlanmaları erkeklerinkine nazaran oldukça gerisinde kalmaktadır. Bu yüzdendir ki kadınların kayda geçmeyen faaliyetlerinin ekonomiye katkısı ülke GSMH'larının 1/3'ü ile 1/2'sine ulaşmaktadır (Aztimur, 2005; 38).

\section{Finansal okuryazarlık}

Bu evrede kadın girişimcilerin erkek girişimcilerle cinsiyet ayrımı gözetmeksizin aynı meslek gruplarında çalışabilme ve rekabet edebilmesi için eksik kaldığı durumlar tespit edildiğinde finansal okuryazarlık alanında geliştirilmesi gereken kesim olarak görüldüğü birçok çalışma mevcuttur. Finansal bilgi düzeyi düşük bireyler verdikleri kararlar sonucunda, daha fazla faiz ödemesi, bilinçsiz yatırım ve zarar etme gibi bir takım olumsuz sonuçlarla karşı karşıya kalmaktadırlar. Kişinin finansal bilgi düzeyinin yükselmesi gerek bireyler gerekse ülke açısından önemlidir. Finansal bilgi düzeyi yüksek bireylerin, tasarruf eğilimleri artmakta, aldıkları önlemlerle zarar etme risklerini azaltmakta ve daha düşük maliyetle yatırımda bulunmalarını sağlamaktadır.

PISA'da yer alan tanıma göre; bireylerin ve toplumun finansal refahını artırmak amacıyla, finansal bilgileri bilme; ilgili kavramları, riskleri ve becerileri anlama; bu bilgi ve anlayışı farklı finansal bağlamlarda etkili kararlar almak için kullanma güdüsü ve güvenine sahip olmak (OECD, 
2013) anlamı içeren finansal okuryazarlık, bireysel yatırımcı olarak tanımlayabileyeceğimiz girişimcilerin yaşadığı sorunlar aynı zamanda ülke genelinde tüm kurum ve kuruluşların da karşılaşabileceği sorunlardır. Hem şirket hem de ülke bazında büyük krizlerin yaşandığı tüm dünya ekonomisini yüksek oranda etkileyen dönemlerde, finansal okuryazarlık düzeyi yüksek olan yöneticilere ve kuruluşlara oldukça ihtiyaç duyulmaktadır.

Devletlerin bireyin finansal okuryazarlık alanındaki yetersizliğini gidermek adına gerek önlem alması gerekse de geliştirici politikalar uygulamaması durumunda gelecekte oluşabilecek finansal sorunlar olarak görülmektedir. Türkiye'de gerek ülke nüfusunun dörtte birlik bir bölümünün kırsal alanda yaşaması gerekse tarımın ülke ekonomisindeki ağırlığ nedeniyle girişimcilik daha da önemli hale gelmektedir (Soysal,2013:168). Literatürde demografik değişkenlerin finansal davranış eğilimleri üzerine etkilerine bakıldığında, kadınların finansal okuryazarlık seviyesinin erkeklere göre daha düşük olup; ayrıca erkeklere oranla daha az borçlanma eğilimi gösterdiklerine rastlanmaktadır (Lusardi ve Tufano, 2009:24). Aslında elindeki sinırlı finansal kaynaklar ile maksimum fayda temin etmek isteyen her bireyin belirli düzeyde finansal okuryazar olması gerekmektedir. Ayrıca bireyin finansal okuryazarlık seviyesinin yüksek olması günlük hayatında kullandığı bir çok finansal kaynağın anlaşılabilir olmasını kılacaktır (Lusardi, 2008: 14).

OECD'nin 2005 yılında ekonomi okuryazarlığı hakkında yaptığı araştırmanın sonuçlarına bakıldığında (Mercan, vd.2012:111-112):

- Avustralya'da araştırmaya katılanların \%67'si bileşik faizin ne demek olduğunu bildiğini iddia etmesine rağmen sadece $\% 28$ 'i bileşik faizle ilgili sorulan soruyu bildikleri,

- İngiltere'de insanlar yatırım kararları konusunda yeterli araştırma yapmadıkları ya da tavsiye almadıkları ve sahip oldukları bilgiye ise rast gele bir banka broşürünü okuyarak ya da bankacilarıyla konuşarak ulaştıkları,

- Kanada'da ise, yatırımcılar doğru yatırım ürününü seçmeyi diş̧̧iye gitmekten daha stresli buldukların,

- Kore'deki lise öğrencilerinin finans okuryazarlığ ile ilgili sorulara \%60'ından az kişinin doğru cevap verdiği, uygun kredi kartının na- 
sıl seçilip kullanılacağı, emeklilik için tasarruf ve yatırım kararlarının nasıl verileceği, risk ve sigortayı kullanarak riskten nasıl korunabileceği konularını içerdiği,

- Amerika Birleşik Devletleri'nde ise her on kişiden dört kişinin bireysel emeklilik hesabına sahip olmadıkları ortaya çıkmıştır.

\section{Araştırmanın yöntemi}

Araştırma, Muğla ili Milas ilçesinde faaliyet gösteren kadın girişimcilerin finansal okuryazarlık düzeylerine ilişkin finansal bilgi, davranış ve tutumlarını belirleme amacına yönelik yapılmıştır. Milas ilçesinde bulunan kadın girişimciler evren olarak kabul edilmiştir.

Toplam 70 kadın girişimciye uygulanan anket sonucunda, geçersiz anketler elendiğinde 54 geçerli anketin istatistiki analizi yapılmıştır. İlçe merkezi ve beldeleri olmak üzere resmi kayttlar dahilinde toplamda 196 kadın girişimci olması nedeniyle bu rakamın 4'te 1'ini oluşturan 54 kişinin örneklemin evrenini temsil edeceğine kanaat getirilmiştir.

$\mathrm{Bu}$ doğrultuda, kadın girişimcilere uygulanan anket verileri demografik ve girişimcilik ile ilgili sorular freakans analizi ve yüzdelik dilimler ile finansal okuryazarlık düzeylerini ölçmeye yönelik sorular ise ki-kare yöntemi ile analiz edilmiştir.

\section{Bulgular}

Çalışmada örneklem kapsamında yer alan kadın girişimcilerin öncelikle yaş, cinsiyet, medeni hal, eğitim durumu, çocuk sayısı, eş mesleği gibi demografik değişkenler ve işletmenin faaliyet süresi, çalışan sayısı, beklenen gelir, gerçekleşen gelir, finansal ihtiyacın sağlanıldığı kaynak, karlılığı etkileyen unsurlar ve karşılaşılan engeller gibi çalışma hayatına yönelik değişkenlerin analizi yapılmıştır.

\section{Araştırmanın hipotezleri}

Araştırmanın amacı ve modeli doğrultusunda araştırma hipotezleri aşağıdaki gibi belirlenmiştir. 
H1: Finansal bilgi düzeyi ile demografik özellikler arasında ilişki vardir.

H2: Finansal tutum ile demografik özellikler arasında ilişki vardır.

H3: Finansal bilgi ile gelir düzeyi arasında ilişki vardır.

H4: Finansal tutum ile gelir düzeyi arasında ilişki vardır.

Tablo 1: Demografik Değişkenler

\begin{tabular}{|c|c|c|c|}
\hline \multirow{6}{*}{ Yaş } & & Frekans & Yüzde \\
\hline & $20-30$ & 12 & 22,2 \\
\hline & $31-40$ & 25 & 46,2 \\
\hline & $41-50$ & 9 & 16,6 \\
\hline & $51-60$ & 8 & 14,8 \\
\hline & Toplam & 54 & 100,0 \\
\hline \multirow{3}{*}{$\begin{array}{l}\text { Medeni } \\
\text { Durum }\end{array}$} & Evli & 35 & 64,8 \\
\hline & Bekar & 19 & 35,2 \\
\hline & Toplam & 54 & 100,0 \\
\hline \multirow{5}{*}{$\begin{array}{l}\text { Eğitim } \\
\text { Durumu }\end{array}$} & İlköğretim & 8 & 14,8 \\
\hline & Lise & 28 & 51,8 \\
\hline & Lisans & 14 & 26,0 \\
\hline & Lisansüstü & 4 & 7,4 \\
\hline & Toplam & 54 & 100,0 \\
\hline \multirow{4}{*}{$\begin{array}{l}\text { Çocuk } \\
\text { Sayısı }\end{array}$} & 1 & 24 & 44,4 \\
\hline & 2 & 20 & 37,0 \\
\hline & 3 ve üzeri & 10 & 18,6 \\
\hline & Toplam & 54 & 100,0 \\
\hline \multirow{6}{*}{$\begin{array}{c}\text { Eş } \\
\text { Mesleği }\end{array}$} & İşçi & 9 & 16,6 \\
\hline & Memur & 23 & 42,5 \\
\hline & Girişimci & 6 & 11,1 \\
\hline & Emekli & 12 & 22,2 \\
\hline & Serbest Meslek & 4 & 7,4 \\
\hline & Toplam & 54 & 100,0 \\
\hline
\end{tabular}

Toplamda 54 kadın girişimciye uygulanan anketin sorularını \%46,2 oranı ile en fazla 31-40 yaş aralığında olanlar, \%14,8 oranı ile en az 51-60 yaş aralığında olan kadınlar cevaplamıştır. \% 64,8 oranı ile kadınların çoğunluğu evli olup $\% 44,4$ oranı ile en fazla 1 çocuk sahibi oldukları, kadınların eşinin mesleği \% 42,5 oranı ile en fazla memur $\% 7,4$ oranı ile en az 
serbest meslek olduğu tespit edilmiştir. Analiz sonucu anket sorularını cevaplayan kadın girişimcilerin $\% 51,8$ oranı ile yarıdan fazlası lise sonrası eğitime devam etmemiş ve $\% 7,4$ oranı ile çok az oranda kadın girişimcinin lisansüstü eğitim aldığı sonucuna ulaşılmıştır.

Tablo 2 : Çalışma hayatına yönelik değişkenler

\begin{tabular}{|c|c|c|c|}
\hline \multirow{6}{*}{$\begin{array}{c}\text { İşletmenin } \\
\text { Faaliyet } \\
\text { Süresi }\end{array}$} & & Frekans & Yüzde \\
\hline & $0-2$ & 8 & 14,8 \\
\hline & $3-5$ & 23 & 42,5 \\
\hline & $6-8$ & 17 & 31,4 \\
\hline & 9 ve üzeri & 6 & 11,1 \\
\hline & Toplam & 54 & 100,0 \\
\hline \multirow{5}{*}{$\begin{array}{l}\text { Çalışan } \\
\text { Sayısı }\end{array}$} & Yok & 38 & 70,3 \\
\hline & $1-10$ & 16 & 29,6 \\
\hline & $11-20$ & - & 0 \\
\hline & 21 ve üzeri & - & 0 \\
\hline & Toplam & 54 & 100,0 \\
\hline \multirow{5}{*}{$\begin{array}{c}\text { Beklenen } \\
\text { Gelir }\end{array}$} & $500-1000$ & 2 & 3,7 \\
\hline & $1001-2000$ & 8 & 14,8 \\
\hline & $2001-3000$ & 25 & 46,2 \\
\hline & 3000 ve üzeri & 19 & 35,1 \\
\hline & Toplam & 54 & 100,0 \\
\hline \multirow{5}{*}{$\begin{array}{c}\text { Gerçekle- } \\
\text { şen } \\
\text { Gelir }\end{array}$} & $500-1000$ & 8 & 14,8 \\
\hline & $1001-2000$ & 10 & 18,5 \\
\hline & $2001-3000$ & 27 & 50,0 \\
\hline & 3000 ve üzeri & 9 & 16,6 \\
\hline & Toplam & 54 & 100,0 \\
\hline
\end{tabular}

Çalışmada kullanılan örneklemde kadın girişimciler \%42,5 oranı ile en fazla 3-5 yıl arasında \%11,1 oranı ile en az 9 yıl ve üzeri süredir faaliyette oldukları belirlenirken, \%70,3 oranında büyük bir çoğunluğun çalışana ihtiyaç duymadığı saptanmıştır. İşletme kuruluş öncesinde tahmin edilen gelir ile kuruluş sonrası elde edilen gelir oranlarına bakıldığında, kuruluş öncesi \%46,2 oranı ile en fazla 2001-3000 TL gelir sağlamayı planlayan kadın girişimciler işletme faaliyete geçtikten sonra \%50,0 oranı ile en fazla 2001-3000 TL arası gelir sağlayarak hedeflenen gelire ulaştıkları belirlenmiştir. 
Tablo 3 : İşletme kuruluş aşaması ve sonrası faaliyet değişkenleri

\begin{tabular}{|c|c|c|c|}
\hline \multirow{6}{*}{$\begin{array}{c}\text { Finansal } \\
\text { İhtiyacın } \\
\text { Sağlandığı } \\
\text { Kaynak }\end{array}$} & & Frekans & Yüzde \\
\hline & Banka & 26 & 48,1 \\
\hline & Eş - Akraba & 19 & 35,1 \\
\hline & Diğer İşletmeler & 3 & 5,5 \\
\hline & Yeni Ortak & 6 & 11,1 \\
\hline & Toplam & 54 & 100,0 \\
\hline \multirow{5}{*}{$\begin{array}{l}\text { Karlılığı } \\
\text { Etkileyen } \\
\text { Unsurlar }\end{array}$} & Kredi Maliyeti & 8 & 14,8 \\
\hline & Personel Giderleri & 19 & 35,1 \\
\hline & Vergi ve Benzeri Ödemeler & 14 & 25,9 \\
\hline & Mal Alım Maliyetleri & 13 & 24,0 \\
\hline & Toplam & 54 & 100,0 \\
\hline \multirow{6}{*}{$\begin{array}{c}\text { Karşılaşılan } \\
\text { Engeller }\end{array}$} & Bürokratik Engeller & 12 & 22,2 \\
\hline & Sermaye Yetersizliği & 28 & 51,8 \\
\hline & Vergi Ödemeleri & 5 & 9,2 \\
\hline & Bilgi Yetersizliği & 6 & 11,1 \\
\hline & Kişisel Nedenler & 3 & 5,5 \\
\hline & Toplam & 54 & 100,0 \\
\hline
\end{tabular}

İşletme kuruluş aşamasında kadın girişimcilerin \% 48,1 oranında en fazlası finansal ihtiyacı sağlamak için banka kredisine, $\% 5,5$ oranında ise en az ise diğer işletmelere başvurduğu belirlenmiştir. İşletme faaliyete geçtikten sonra; karlılığı etkileyen unsurları belirlemek amaciyla yöneltilen soruları cevaplayan kadın girişimcilerin $\% 25,9$ oranı ile en fazla vergi ve benzeri ödemeler \%14,8 oranı ile ise en az kredi maliyetinin karlılık durumunu etkilediği ortaya çıkmaktadır. Analiz sonucunda \% 51,8 oranında kadınların yarısından fazlasının sermaye yetersizliği engeli ile karşılaştığ 1 tespit edilmiştir.

Tablo 4 : Kadın girişimcilerin bilgi ve beceri kaynă̆ına ilişkin bulgular

Becerilerin Kazanıldığı Kaynak Ekonomik ve Finansal Gelişmelerin Takip Edildiği Kaynak

\begin{tabular}{lcclcc}
\hline & Frekans & Yüzde & & Frekans & Yüzde \\
\hline Kitap-Dergi & 5 & 9,2 & Internet & 16 & 29,6 \\
\hline Okul & 25 & 46,2 & Televizyon & 14 & 25,9 \\
\hline Aile & 20 & 37,0 & Gazete ve Dergi & 14 & 25,9 \\
\hline Arkadaş & 4 & 7,4 & Kitap & 10 & 18,5 \\
\hline Toplam & $\mathbf{5 4}$ & $\mathbf{1 0 0}$ & Toplam & $\mathbf{5 4}$ & $\mathbf{1 0 0 , 0}$ \\
\hline
\end{tabular}


Araştırmanın örneklemini oluşturan kadın girişimcilerin \% 46,2 oranında çoğunluğunun okul aracılığıyla finansal okuryazarlık becerilerini kazandığı, \% 29,6 oranında kadın girişimcinin ise ekonomik ve finansal gelişmeleri internetten takip ettiği saptanmıştır.

\section{Finansal bilgiye ilişkin bulgular}

Finansal okuryazarlığın belirlenmesinde temel bileşenlerden biri finansal bilgi düzeyidir. Kadın girişimcilerin temel seviye finansal bilgi düzeyini belirleyebilmek amacı ile yedi soru yöneltilmiştir.

Tablo 5 : Finansal bilgi soruları ve sorulara verilen doğru ve yanlış cevap dağılımı

\begin{tabular}{lccc}
\hline \multicolumn{1}{c}{ Sorular } & Doğru & Yanlış & $\begin{array}{c}\text { Doğru Cevap Yüz- } \\
\text { desi }\end{array}$ \\
\hline Dört İşlem & 46 & 8 & 85,1 \\
\hline Basit Faiz & 12 & 42 & 22,2 \\
\hline Bileşik Faiz & 5 & 49 & 9,2 \\
\hline Çeşitlendirme & 12 & 42 & 22,2 \\
\hline Faiz-Enflasyon İlişkisi & 14 & 38 & 25,9 \\
\hline Risk-Getiri İlişkisi & 9 & 45 & 16,6 \\
\hline Finansal Ürün Bilgisi & 11 & 43 & 20,3 \\
\hline
\end{tabular}

Kadın girişimcilerin finansal bilgi düzeyini belirlemek amacıyla yöneltilen dört işlem sorusuna $\% 85,1$ oranında, basit faiz sorusuna $\% 22,2$ oranında, bileşik faiz sorusuna $\% 9,2$ oranında, çeşitlendirme sorusuna $\% 22,2$ oranında, faiz-enflasyon ilişkisi sorusuna \%25,9 oranında risk-getiri ilişkisi sorusuna \%16,6 son olarak finansal ürün bilgisi sorusuna ise \% 20,3 oranında doğru cevap verildiği tespit edilmiştir. Analiz sonucuna bakıldığında, diğer değişkenlerin yüzdelik oranları arasında çok fark olmamakla birlikte \%85,1 oranı ile en fazla dört işlem sorusu doğru cevaplandığı saptanmıştır.

Tablo 6 : Finansal bilgi başarı düzeyine ilişkin frekans ve yüzde dağılımı

\begin{tabular}{lcc}
\hline $\begin{array}{l}\text { Finansal bilgi başarı } \\
\text { düzeyi }\end{array}$ & Frekans & Yüzde \\
\hline Başarılı & 32 & 59,2 \\
\hline Başarısız & 22 & 40,8 \\
\hline Toplam & $\mathbf{5 4}$ & $\mathbf{1 0 0}$ \\
\hline
\end{tabular}


Araştırmanın örneklemini oluşturan 54 kadın girişimcinin finansal bilgi düzeyinin $\% 59,2$ oranında başarılı olduğu sonucuna ulaşılmıştır.

Tablo 7 : Finansal davranış düzeyine ilişkin frekans ve yüzde dă̆ılımı

\begin{tabular}{lcc}
\hline Son bir yıl içinde birikim yaptınız mı? & Frekans & Yüzde \\
\hline Evet & 30 & 55,5 \\
\hline Hayır & 24 & 44,4 \\
\hline Toplam & $\mathbf{5 4}$ & $\mathbf{1 0 0 , 0}$ \\
\hline Son bir yıl içinde borç kullandınız mı? & & \\
\hline Evet & 40 & 74,0 \\
\hline Hayır & 14 & 26,0 \\
\hline Toplam & $\mathbf{5 4}$ & $\mathbf{1 0 0 , 0}$ \\
\hline
\end{tabular}

Kadın girişimcilerin finansal okuryazarlık bileşenlerinden biri olan finansal davranış düzeyine ilişkin yaptıkları birikim ve borç kullanma oranları belirlenmeye çalışılmıştır. \%55,5 oranı ile anket sorularını yönelttiğimiz kadınların yarısından fazlasının son bir yıl içinde birikim yaptığı ve aynı zamanda $\% 74,0$ oranında kadınların büyük çoğunluğunun borç kullandığı tespit edilmiştir.

Tablo 8 : Finansal tutum ile demografik özelliklere ilişkin ki-kare analizi sonuçlan

\begin{tabular}{|c|c|c|c|c|c|c|c|c|}
\hline & & \multicolumn{2}{|c|}{ Olumlu } & \multicolumn{2}{|c|}{ Olumsuz } & \multirow{2}{*}{$X$} & \multirow{2}{*}{$\mathbf{P}$} & \multirow{2}{*}{$\begin{array}{c}\text { İlişki } \\
\text { miktarı } \\
(\%)\end{array}$} \\
\hline & & f & $\%$ & f & $\%$ & & & \\
\hline \multirow{4}{*}{ Yaş } & $21-30$ & 3 & 15 & 9 & 38 & \multirow{4}{*}{0,457} & \multirow{4}{*}{0,547} & \multirow{4}{*}{4,6} \\
\hline & $31-40$ & 7 & 35 & 8 & 33 & & & \\
\hline & $41-50$ & 6 & 30 & 3 & 12 & & & \\
\hline & $51-60$ & 4 & 20 & 4 & 17 & & & \\
\hline \multirow{4}{*}{$\begin{array}{l}\text { Eğitim } \\
\text { Düzeyi }\end{array}$} & İlkokul & 4 & 15 & 4 & 14 & \multirow{4}{*}{2,457} & \multirow{4}{*}{0,069} & \multirow{4}{*}{10,7} \\
\hline & Lise & 7 & 27 & 21 & 75 & & & \\
\hline & Lisans & 12 & 46 & 2 & 7 & & & \\
\hline & Yüksek Lisans & 3 & 12 & 1 & 4 & & & \\
\hline \multirow{4}{*}{ Gelir } & $500-1000$ & 2 & 8 & 0 & 0 & \multirow{4}{*}{3,77} & \multirow{4}{*}{0,045} & \multirow{4}{*}{12,7} \\
\hline & $1001-2000$ & 3 & 12 & 5 & 17 & & & \\
\hline & $2001-3000$ & 11 & 44 & 14 & 48 & & & \\
\hline & 3001 ve üzeri & 9 & 36 & 10 & 35 & & & \\
\hline
\end{tabular}

${ }^{*} \alpha=0,05$ düzeyinde ilişki anlamlıdır. 
Kadınların finansal okuryazarlık bileşenlerinden biri olan finansal tutumları ile demografik özellikleri arasındaki ilişkiyi saptamak amacıyla ki-kare analiz yönteminden yararlanılmıştır. Kadın girişimcilerin yaş aralığı, eğitim seviyeleri ve gelir düzeyleri arasında anlamlı bir ilişki olup olmadığı tespit edilmeye çalışılmıştır. Analiz sonuçları ele alındığında; 0,05 düzeyinde ve bu rakama yakın oranlar değişkenler arasında anlamlı bir ilişki olduğunu göstermektedir. Bu doğrultuda, 0,069 oranının \%10,7 ile eğitim düzeyi ve 0,045 oranının \%12,7 ile gelir düzeyinin finansal tutum ile arasında anlamlı bir ilişki olduğu belirlenmiştir. 0,547 oranının 4,6 ile kadınların yaşının finansal tutum arasında anlamlı bir ilişki olmadığı ortaya çıkmıştır.

\section{Sonuç}

Finansal bilgi, finansal davranış ve finansal tutum gibi unsurlardan oluşan finansal okuryazarlık, bireylerin gelirlerini, borçlarını, tasarruflarını ve harcamalarını yönetebilme yeteneği olarak ifade edilmektedir. Finansal okuryazarlık düzeyinin artması, kişilerin alacakları finansal kararların başarısını arttıracaktır.

Finansal bilgi, finansal davranış ve finansal tutum gibi unsurlardan oluşan finansal okuryazarlık, bireylerin gelirlerini, borçlarını, tasarruflarını ve harcamalarını yönetebilme yeteneği olarak ifade edilmektedir. Finansal okuryazarlık düzeyinin artması, kişilerin alacakları finansal kararların başarısını arttıracaktır.

Finansal okuryazarlık kavramı her bireyin elde ettiği geliri nasıl yöneteceği konusunda çalışma hayatının yanı sıra bireysel hayatında da önemli bir rol oynamaktadır. Finansal okuryazarlık her ne kadar sonradan edinilen bir kavram olarak görülse de; bireyin eğitim hayatının başlamasıyla sürekli yeni bilgi edinme gereksinimiyle devam eden bir süreç olarak nitelendirilebilir. Bu aşamada kadınların hem bir aile ferdi olarak bireyin eğitimine olan katkısı sebebiyle hem de kendi çalışma hayatında başarılı olabilmesi açısından finansal okuryazarlık düzeyinin yüksek olması beklenilmektedir. 
Bu çalışmada, kadın girişimcilere anket uygulayarak finansal okuryazarlık seviyesi, finansal okuryazarlık konusunda ki yeterlilikleri, bazı finansal kavramlar hakkında ki bilgi düzeyleri ve güncel finansal gelişmelerle ilgilenme durumlarının tespit edilmesi amaçlanmıştır. Elde edilen veriler üzerinde çeşitli analizler yapılarak, belirli sonuçlara ulaşılmıştır.

Çalışmaya göre ekonomik ve finansal gelişmelerin izlendiği başlıca kaynaklar arasında gazete-dergi, televizyon ve internet gelmektedir. Çoğunlukla finansal gelişmeleri takip etmek için interneti kullananların oranı \% 29,6 olarak belirlenmiştir. Bu sonuç kadın girişimcilere yönelik tasarlanacak finansal okuryazarlık eğitimleri için en uygun sunum ortamının ne olması gerektiği konusunda yardımcı olmaktadır. Gazete-dergi ve televizyon gibi araçların kullanımı \%25,9 ile birbirine yakın oranlarda olduğundan finansal okuryazarlık eğitimi konusunda en etkili yöntemin internet olduğu görülmektedir.

Kadın girişimcilerin dört işlem, basit faiz, bileşik faiz, çeşitlendirme, faiz-enflasyon ilişkisi, risk-getiri ilişkisi ve finansal ürün bilgisi gibi finansal bilgi düzeyini ölçmek için yöneltilen sorularda \%85,1 oranı ile en fazla dört işlem soruları doğru cevaplanmıştır. Analiz sonucu doğrultusunda çalışmaya dahil edilen kadın girişimcilerin finansal okuryazarlık düzeylerinin oldukça düşük ve bu alanda eğitime ihtiyacı oldukları saptanmıştır.

Araştırmanın örneklemini oluşturan kadın girişimciler son bir yıl içerisinde 55,5 oranı ile birikim yaparken aynı süreçte $\% 74,0$ oranında borç kullandıkları da tespit edilmiştir. Bu durumda kadın girişimcilerin çoğunluğu borçlanarak faaliyetlerini sürdürmektedir.

Finansal tutum ile demografik özellikler arasında anlamlı bir ilişki olup olmadığını tespit etmek amacıyla yaş, eğitim seviyesi ve gelir düzeyi ele alınarak ki - kare yöntemi yardımıyla analiz edilmiştir. 0,069 oranı ile eğitim düzeyi ve 0,045 oranı ile gelir düzeyinin finansal tutum ile arasında anlamlı bir ilişki olduğu belirlenmiştir. 0,547 oranı ile kadınların yaşının finansal tutum arasında anlamlı bir ilişki olmadığı ortaya çıkmıştır. 


\section{Kaynakça}

Aztimur, H. (2005). GAP bölgesinin sosyo-ekonomik kalkınmasında kadın istihdamının yeri: Şanlıurfa örneği. Yayınlanmamış Yüksek Lisans Tezi, Harran Üniversitesi Sosyal Bilimler Enstitüsü, Şanlıurfa.

Bedük, A. (2005). Türkiye'de çalışan kadın ve kadın girişimciliği. Elektronik Sosyal Bilimler Dergisi, 3(12), 106-117

Cici, E. N. (2013). Kadınların Girişimcilik Yolunda Karşılaştıkları Sorunların Öz Girişimcilik Yetenekleri Üzerindeki Etkisi: Konya İlinde Bir Araştırma. Yayınlanmamış Yüksek Lisans Tezi, Selçuk Üniversitesi Sosyal Bilimler Enstitüsü, Konya.

Ecevit, Y. (1993). Aile, kadın ve devlet ilişkilerinin değerlendirilmesinde klasik ve yeni yaklaşımlar. Kadın Araştırmaları Dergisi, 1, 19-20.

Erdun, Ş. (2011). Kadın girişimcilerin risk alma eğilimi ve kendine güven özellikleri üzerine bir çalışma: Zonguldak örneği. Yayınlanmamış Yüksek Lisans Tezi, Zonguldak Karaelmas Üniversitesi Sosyal Bilimler Enstitüsü, Zonguldak.

Gazioğlu, T. E. ve Kurt, Ü.(2015). Ardahan'daki kadın girişimciler: Sorunlar, engeller. Ardahan Üniversitesi İktisadi Ve İdari Bilimler Fakültesi Dergisi, 2, 125-135.

Gökmen, H. (2012). Finansal okuryazarlık. İstanbul: Hiperlink Yayınları, Ss.39.

K1lıç, Y., Ata, H. A., ve Seyrek, İ. H. (2015). Finansal okuryazarlık: Üniversite öğrencilerine yönelik bir araştırma. Muhasebe Ve Finansman Dergisi, Nisan/2015, 129-150.

Lusardi, A., ve Mitchell, O. S. (2011). Financial literacy around the world:

An overview. Journal of Pension Economics and Finance, 10(4), 497-

508. https://doi.org/10.1017/S1474747211000448

Lusardi, A. (2008). Financial literacy: An essential tool for informed consumer choice. Cambridge: Joint Center For Housing Studies Harvard University, Ss.14.

Lusardi, A. ve Tufano, P. (2009). Debt Literacy, financial experiences, and over in debtedness. National Bureau Of Economic Research Working Paper, Ss.44. 
Memiş, H., Paksoy, H. M. ve Paksoy S. (2007). Bölgesel kalkınmada kadın girişimciliğinin önemi: GAP bölgesinde bir araştırma. Girişimcilik ve Kalkınma Dergisi, 2(2), 137-152.

Mercan, N., Oyur, E. Altınay, A. ve Aksanyar, Y. (2012). Ekonomi okur yazarlığına yönelik ampirik bir araştırma. Ekonomi Bilimleri Dergisi, 4(2), 111-112.

OECD Infe. (2013). Measuring Financial Literacy: Results Of The OECD / International Network On Financial Education (Infe) Pilot Study. Paris: Oecd,

Soysal, A. (2013). Kırsal alanda kadın girişimciliği: Türkiye için durum değerlendirmesi. Eskişehir Osmangazi Üniversitesi İktisadi ve İdari Bilimler Dergisi, 8(1), 163-190

Soysal, A. (2010). Türkiye'de kadın girişimciler: Engeller ve fırsatlar bağlamında bir değerlendirme. Ankara Üniversitesi SBF Dergisi, 65(1), 83-114.

Taft, M. K., Z. Hosein, S. M. T. Mehrizi ve A. Roshan. (2013). The Relation Between Financial Literacy, Financial Wellbeing And Financial Concerns. International Journal of Business and Management, 8(11), 63-75.

\section{Kaynakça Bilgisi / Citation Information}

Kutukız, D. ve Özden C. (2018). Kadın girişimciliği ve finansal okuryazarlığın kadın girişimciler üzerindeki etkisi. OPUS - Uluslararası Toplum Araştırmaları Dergisi, 8(Gençlik Araştırmaları Özel Sayısı), 349-365. 